Др ПЕТАР В. КРЕСТИЋ, научни саветник Историјски институт, Кнез Михаилова 36/II

Београд, Србија

Е-адреса: petar.krestic@iib.ac.rs

\title{
ЕВГЕН ДУМЧА ГРАДОНАЧЕЛНИК СЕНТАНДРЕЈЕ И ДОБРОТВОР СРПСКОГ ПРИВРЕДНОГ ДРУШТВА „ПРИВРЕДНИК”
}

САЖЕТАК: Рад пружа кратак приказ живота и делатности Евгена Думче, градоначелника Сентандреје, једног од највећих српских добротвора из Угарске, великог патрона Привреgника, члана Управе Срйске банке g. g. у Заіребу и председника њене будимпештанске филијале.

КљУЧНЕ РЕЧИ: Евген Думча, Сентандреја, Српско привредно друштво „Привредник”, Српска банка, Петронела Думча

Једна од значајних личности која је, како обимном финасијском помоћи тако и личним ангажовањем, значајно допринела изузетно успешним резултатима рада Српског привредног друштва „Привредник”l био је трговац и велепоседник Еуген Думча² (Пешта, 1838 - Сентандреја, 1917). Потекао из цинцарске породице, гимназију и високу трговачку школу завршио је у Бечу, а потом се 1850. настанио у Сентандреји. Трговао је кљуком и вином, а доцније и другом робом. Био је потпредседник Српског народног црквеног сабора, председник Црквене општине, члан Епархијске конзисторије, члан потом потпредседник Административног одбора, потпредседник Епархијске скупштине, члан Управе Срӣске банке g. g. у Зайребу и председник њене филијале

\footnotetext{
${ }^{1}$ Опширније о томе видети: Петар В. Крестић, Срйско йривреgно ярущйво „Привреgник” (1897-1918), Београд 2002.

2 Више о Думчи и његовом раду видети: АС, Привреяник, несређено, кут. 920; Привреgник, бр. 15, јул 1909, 178; Привреgник, бр. 4, фебруар 1912, 50; Привреgник, бр. 9, мај 1912, 113; С. Чампраг, Срйсйво у Сенйаняреји йослеgюих 40 їодина, приредио Петар В. Крестић, Н. Сад - Београд - Будимпешта 2018, 21-23, 28-30, 32-36, 39-40, 44-45, 92, 119; Федора Бикар, „Евген Думча (1838-1917) први градоначелник Сентадреје”, Сенйандрејски зборник, 1, Београд 1987, 203-223; Dumtsa Jenö Emléketete. Tanulmányok, cikkek, dokumentumok, Szentendre 2001, 7-83; Ф. Бикар, „Думча, Евгеније”, Срииски биоїрафски речник 2 (2007), 445-446.
} 
у Будимпешти. ${ }^{3}$ За бирова Сентандреје изабран је 1868 , када је, као способан финансијски стручњак откупио од Коморе за 44.000 форинти ерарске земље са регалним правом. Извршио је и реорганизацију управе Сентандреје, која је од варошице прерасла у град са уредним магистратом, да би 1872. постао њен први градоначелник. На овом положају налазио се 27 година (до 1903) и за то време значајно је допринео развоју града. За његово име везано је економско снажење Сентандреје, али и исушивање ритова и тршчара (1863-1882), изградња одбрамбених насипа према Дунаву и калдрмисање сентандрејских улица (1874).

Думча се 1862. оженио Петронелом Блажић, с којом је основао бројне задужбине. Прве задужбине основао је при Српској црквеној општини 1883. и 1884, у време када је филоксера увелико уништавала сентандрејске винограде и када је становништво, које је живело од прихода добијених од продаје грожђа и вина осиромашило. ${ }^{4}$ Камата од прве закладе у износу од 25 форинти (5\% од 500 форинти основице) имала се сваке године на Бадњи дан издати ,,једној сиротој поштеној девојци, овдашњег грађанина, или једном ученику, мештанину, а који на страни учи". 5 Услед великог притиска на ову, тзв. божићну закладу, на ону основану 1885. на дан Св. Николе, као и на закладу основану маја 1912 , поводом 50 -годишњице свог брака ${ }^{6}$, Думча

3 Филијала у Будимпешти отворена је 1. јуна 1903. Председник је био Евген Думча, велепоседник из Сентандреје, а директор Стеван Карамата.

4 Ф. Бикар, нав. дело, 211.

5 Архив Црквене општине Сентандреја, Зайисник скуйщйине бр. 48/1884.

6 За многе просветне и хумане установе у Карловачкој митрополији приложио је своту од готово 50.000 златних круна. Ево како изгледа списак Думчиних донација које је приложио у само једној години: „Врли српски родољуб и добротвор господин Еуген Думча и супруга му госпођа Петронела, и Привредникови велики добротвори и чланови Патроната - прославили су на Ђурђевдан педесетгодишњицу свог сретног брачног живота, па су том приликом, уз досадња своја силна добра дела основали и ове велике задужбине.

За градњу школских зграда у будимској епархији српским православним црквеним општинама: Бати 3.500 круна, Чипу 2.500 круна, Калазу 500 круна, Илочцу 500 круна, Литоби 500 круна, Дољ. [Доњој] Нани 500 круна, Жумберку 500 круна, Ланчуту 500 круна, Вемену 500 круна, Српском Гарчину 500 круна, разним месним установама у Сентандрији 7.500 круна; за оправку збешке цркве 500 круна, српској православној црквеној општини у Црвеној Цркви за оправку цркве 500 круна, Српској Православној Просветној Женској Задрузи 'Свете Мајке Ангелине' у Будимпешти 2.000 круна, Српском Трговачком и Занатлијском друштву 'Слози' у Будимпешти 500 круна, Друштву 'Коло Младих Срба' у Будимпешти 500 круна, Српској православној великој гимназији у Новом Саду 2.000 круна, Српском Народном Позоришту у Новом Саду 1.000 круна, Српском Учитељском Конвикту у Новом Саду 500 круна, Трговачкој Омладини у Новом Саду 500 круна, 'Слози', удружењу бивших ученика и ученица српске велике гимназије у Новом Саду 500 круна, Друштву за потпомагање српских ђака у Прагу 500 круна, Интернату-алумнеуму српске православне мушке учитељске школе у Сомбору 1.000 круна, Интернату српске православне мушке учитељске школе у Пакрацу 1.000 круна, Српској православној вероисповедној женској школи у Горњем Карловцу 1.000 круна, Српском академском друштву за помагање сиромашних а вредних Срба у краљевском свеучилишту у Загребу 1.000 круна, Добротворној Задрузи Српкиња у Загребу (као чланарину) 500 круна, Добротворној Задрузи Српкиња у Загребу за градњу Интерната 1.000 круна, Добротворној Српској Женској Задрузи у Осеку 500 круна, Српској православној великој гимназији у Сремским Карловцима 2.000 круна, Српском народном црквено-школском фонду Св. Саве у Сремским Карловцима 1.000 круна, Богословском књижевном друштву 'Слози' у Сремским Карловцима 500 круна, Српском соколском друштву 
је током година преко Магистрата оснивао разне фондове за сиротињу различитих вероисповести. ${ }^{7}$ Пошто је имао изражен осећај припадности српском народу свакако да је највише помагао српско-православно становништво. Из тих разлога је по разним местима Будимске епархије подизао школске зграде и давао велике новчане прилоге за њихову изградњу, ${ }^{8}$ па су га савременици сматрали за једног од „највећих добротвора српског народа с ове стране Саве и Дунава". ${ }^{9}$

Поред фондова које је основао при Црквеној општини и Градској кући у Сентандреји, једно од његових највећих завештања била је „Фундација Евгена и Петронеле Думча у Сентандреји" Привреgнику. Као члан Патроната ${ }^{10}$ Привреgника од његовог оснивања ${ }^{11}$ и патрон његових фондова Думча је овом друштву у периоду од 1909. до 1914. приложио 52.000 круна. Закладним писмом од 4. августа 1909. Думча је 10.000 круна посветио у Привреgникове сврхе, и тако основао поменуту фондацију. Већ 1911. фондацију је увећана за 5.000 круна, а 25. марта 1914. приложио је нових 33.000 круна. Евген и Петронела Думча помагали су Привреgников шегртски фонд и годишњим приносима, који су трошени на свакодневне потребе друштва. У то име само до марта 1914. приложили су додатних 4.695 круна. Својим закладним писмом из 1909. одредили су да се приход тог фонда „употребљава за свагдање најпрече потребе, али увек само у сврхе придизања српског православног привредног подмлатка, који је дужан - посље своје праксе у српске крајеве вратити се, у српским крајевима своје самосталне радње отварати и са православним Српкињама оженити се."12 Предајући свој последњи дар

\footnotetext{
у Сремским Карловцима 1.000 круна, Српском соколском друштву у Беловару 500 круна, Српском соколском друштву у Двору 500 круна, Српској православној црквеној општини у Помазу 1.000 круна, Српској православној црквеној општини у Чобанцу 500 круна, Српској православној црквеној општини у Будакалазу 500 круна, Српској православној црквеној општини у Ловри 500 круна.

Ове најновије задужбине одличних српских јубилара износе преко 40.000 круна, а закладне своте доставиће се преко Будимпештанске Филијала Загребачке Српске Банке.

Српски народ је одувек имао великих и племенитих својих синова и кћери, који су давали и прилагали на олтар народни. Примеру њиховом следују, а новима коленима предњаче супрузи Думче ретким и управо ненадмашним родољубљем.

Нека им је хвала и у име наше и у име целог српског народа, а глас о том њиховом великом делу одјекује већ по целом Српству" [Подвукао П. В. Крестић] (Привреgник, бр. 9, мај 1912, 112-113).

7 Ф. Бикар, нав. gело, 212-213.

8 Привредник, бр. 4, фебруар 1912, 50; Привреgник, бр. 9, мај 1912, 113.

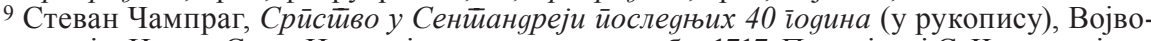
ђански музеј у Новом Саду, Историјско одељење, инв. бр. 1717. Протојереј С. Чампраг је то могао са сигурношћу знати, пошто је, поред дужности дугогодишњег конзисторијалног бележника будимске епархије у Сентандреји, био и повереник Привреgника у овом месту.

${ }^{10}$ Патронат је као највиша Привреgникова установа био дужан да се заузима за ширење покрета, за прикупљање чланова и добротвора, оснивање нових задужбина, покретање и спремање омладине за практичан, стручан и напредан рад ради што бржег и бољег обнављања модерне привреде свих струка.

11 У Привреgниковом Патронату у време оснивања, 10/23. септембра 1911, међу 45-оро оснивача били су и брачни пар Евгеније и Петронела Думча, добротвори Привреgника из Сентандреје (Оснивачка седница и I редовна седница Пайронайа Привреgникових фонgова, Загреб, 10. IX 1911).

12 АС, Привреgник, несређено, кут. Циркулари.
} 
Привреgнику, Думча је рекао: „Ево од свега срца, а ако нас Бог поживи ми мислимо и желимо још учинити за ту нашу најважнију установу". 13

У знак признања Привреgник је публиковао његово закладно писмо у облику малог плаката, са фотографијама донатора, супружничког пара Думча.

Брачни пар Думча целог живота живео је скромно. Иако добар финансијер, Евген је начинио грешку уздајући се у стабилност вредности новца, па је своју четвороспратну кућу у Будимпешти пред Први светски рат продао и уложио у вредносне папире и акције, које су већ током његовог живота изгубиле на вредности, а после рата су постале безвредне. Петронела је после смрти супруга живела са сестром, удовицом сентандрејског професора и пароха Јована Пачариса. По окончању рата преселила се у Нови Сад, где је боравила у кући сестриног зета др Александра Димшића, потоњег председника Касационог суда. Како је из поменутог разлога остала без икаквих прихода, издржавала се од пензије коју јој је, као држављанки Мађарске, а заслужној грађанки, доделила Сентандреја. Упркос чињеници да је одредбама закладног писма уживала право на коришћење доживотног прихода од суме коју су супружници Думча поклонили Привреgнику, ни после супругове смрти 1917. Петронела никада није подигла ни најмању своту новца од камате, иако јој је тај новац током година у више наврата нуђен од стране овлашћених представника Привреgника.

Од самог свог настанка, 1897, па све до краја Другог светског рата, Привреgник је играо кључну улогу у осамостаљивању, снажењу и унапређивању српске привреде. За успех у остварењу ове племените мисије ово друштво дугује захвалност пре свих племенитим људима попут Евгена и Петронеле Думча. Препознавши свесрпски карактер покренуте иницијативе, најистакнутији представници српске привреде, српско грађанство с различитих подручја Монархије - Аустрије, Босне и Херцеговине и Јужне Угарске, као и из свих других подручја насељених Србима, укључујући, свакако, матичну државу, радо и крајње несебично су се прикључили њеној реализацији, свесни њене изузетне важности за јачање националне самосвести Срба у Хабзбуршкој монархији, али и српског народа у целини. 
PETAR V. KRESTIĆ, PhD, senior research fellow Institute of History, Knez Mihailova 36/II, Belgrade, Serbia

E-mail: petarkre@mts.rs

\section{EUGEN DUMČA, THE MAYOR OF SZENTENDRE AND THE BENEFACTOR OF THE SERBIAN BUSINESS SOCIETY “PRIVREDNIK”14}

SUMMARY: The paper gives a brief overview of the life and work of Evgen Dumča, merchant, landowner and mayor of Szentendre, one of the largest Serbian benefactors from Hungary, the great patron of Privrednik, a member of the Management Board of Serbian bank a.d. in Zagreb and the president of its Budapest branch. His significant contribution was emphasized, expressed in both extensive financial assistance and personal engagement, which provided for the emergence and strengthening of the Serbian business association "Privrednik", as well as other institutions of the Serbian people in Hungary. The emphasis is on his great contribution expressed in both extensive financial assistance and personal engagement, which provided for the emergence and strengthening of the Serbian business association "Privrednik", as well as other institutions of the Serbian people in Hungary. As one of the "greatest benefactors of the Serbian people on this side of the Sava and the Danube", Dumča founded the "Eugene and Petronella Dumča Foundation in Szentendre" for Privrednik. In the period from 1909 to 1914, he contributed 52,000 crowns to this Society, and in a Foundation Letter dated August 4, 1909, he dedicated 10,000 crowns for the needs of Privrednik. As early as 1911, he increased the foundation by 5,000 crowns, and in 1914 he donated a new 33,000 crowns. At the same time, Dumča spouses helped Privrednik's apprenticeship fund with annual returns.

KEYWORDS: Evgen Dumča, Szentendre, Serbian Business Association "Privrednik", Serbian bank, Petronela Dumča 